\title{
MONOPOLY CAPITAL AND ITS INSULATION FROM COUNTERVAILING POWER: AMERICAN CAPITALISM REVISTED
}

Kichiro Iwamoto

University of Santa Clara

David Willer

University of Kansas

Mid-American Review of Sociology, 1979, Vol IV, No. 2:1-15

\section{THE IDEA OF COUNTERVAILING POWER}

This paper will discuss, critique, and revise John Kenneth Galbraith's 'theory of countervailing power.' Galbraith (1952) attempted to answer the question: what prevents some organizations in capitalist economic systems from developing market power, which can control and stifle free economic exchange? In the 19th century it was thought that competition among businesses each sharing a small part of the total market would restrict any one organization from establishing economic power.

It was assumed ... that the nineteenth-century textile manufacturer who overcharged for his product would promptly lose his market to another manufacturer who did not. If all manufacturers found themselves in a position where they could exploit a strong demand, and mark up their prices accordingly, there would soon be an inflow of new competitors. The resulting increase in supply would bring prices and profits back to normal (Galbraith, 1952:110).

Galbraith also argued that manufacturers were further checked because those who paid lower wages would in time lose their labor force to those who paid more. Given similar types of restraints for the buyers, a self-regulating mechanism in the economy could be postulated by classical economists. Let us describe the open competitive market in slightly different terms. This approach assumes that there is a limited profit range within which any manufacturer will operate. A company will have an interest in 
remaining in a given business network if it can make a profit equal to or greater than it can earn through investing (that is, at least equal to or more than the current bank interest rates). Moreover, in the open market, other manufacturing competitors limit how much any company can increase prices of the product above the current market price. For example, if the current bank interest rate is 7 percent then we would expect a company to make more than a 7 percent but less than 9 or 10 percent profit. Let us consider how this top limit is determined.

When considering a simple model of this market system, it is first necessary to identify the potential network of economic relationships, for if one is to understand how any one economic actor (in this case a company) is behaving, it is important to recognize the range of possible choices. (See Figure 1 . These and other figures are in the appendix.)

Now let it be assumed that at a point in time the actual network of Figure 2 exists. In this case customers $\mathrm{K}$ and $\mathrm{N}$ are purchasing commodities from two of the three manufacturers: $A$ and $B$, and $A$ and $C$ respectively. If $A$ decides to raise the price of the product then A's customers will turn to $B$ and $C$ who have maintained lower prices. That is, if $\mathrm{K}, \mathrm{L}, \mathrm{M}$, and $\mathrm{N}$ behave rationally they will seek the lowest price for the desired commodity and exclude A from the system. Under these conditions manufacturer A can either lower its price or be forced out of business. This then is the starting point of a network interpretation of the self-balancing marketplace.

However, as Galbraith pointed out, with the decline of open competition and the development of small groups of extremely large corporations, markets are no longer self-balancing. But he also contended that it is erroneous to assume that all forms of economic restraint on monopolistic market power had vanished.

It is at this point that Galbraith introduces his concept of countervailing power as a new restraint on what he calls private (monopolistic) power. Where the old restraint was created by external pressure of competition, the new form was internally based and developed by the corporation's customers and/or suppliers. With the development of a few 'strong sellers' by the concentration of industries in the control of few firms, there also developed, unnoticed by economists (but for Galbraith), 'strong buyers.' The fact that large corporations are able to develop monopolistic power (that is, to generate prevailing power) is the very inducement that motivates customers and suppliers to create their own defense mechanisms against exploitation.

According to Galbraith, "The opportunity to exercise... [countervailing] ... power exists only when the suppliers are enjoying something that can be taken away; i.e., when they are enjoying the fruits of market power from which they can be separated" (1952:118). That is, market power can result in profits above the level that would have been expected in a perfect market. We will call this increment in profits prevailing power. To question how prevailing power is countervailed and how far that countervailence can proceed, is to ask how high profit levels can be reduced and whether they can be reduced to the levels that would have been typical of a perfect market.

To understand his position, let us begin with a model indicating the potential networks between the manufacturer, the retailer and the customer (see Figure 3). In reality the retailer usually deals with a very large potential customer market, but for simplicity the model will represent all the individual customers as one aggregate social actor.

To understand countervailing power let us initially focus on the manufacturer-retailer relationship, and make the assumption that A has 50 percent of the supplier's market, B 30 percent and C 20 percent. The basic conditions for an oligopoly are present in this example. Manufacturer A, having a much larger percentage of the market, can raise prices in order to increase profits. Since A produces for such a large portion of the market, manufacturers $B$ and $C$ would not be expected to have either the capabilities or the capital to take the risk of increasing production in order to absorb portions of A's market upon A's price increase, for if A should suddenly lower its price to its original point or even slightly below the original price $B$ and/or $C$ would end up with surplus merchandise which might be sufficient to drive them out of business.

Under these conditions it is the retailer that Galbraith identifies as the possible initiator of countervailing power. An example he refers to is the development of large powerful retail enterprises 


\section{Mid-American Review of Sociology}

such as Sears Roebuck (see Galbraith, 1952:119ff). By using their market 'power' to purchase large quantities of tires at 25 to 40 percent lower than market value, the tires can be resold then to customers at 20 to 25 percent less than the normal retail price. Under these conditions Sears would have countervailed the power of oligopolistic tire manufacturers such as Goodyear Tire and Rubber Company. Generally Galbraith believes that at the end of most marketing channels there is a powerful retailer who can countervail the power of the producer. In an attempt to offer lower prices to customers as a way for maintaining customer markets, large retail competitors must deal with the threat of rapid growth of rivals and/or the appearance of new businesses that would cause a loss of volume of sales and, in turn, destroy the conditions that allow that company to offer customers lower prices. Therefore, Galbraith argues, these large retailers are very sensitive to increased prices by manufacturers, and they are for this reason motivated to countervail the power of the manufacturer. With reference to increased prices, though not always clearly stipulated in his argument, Galbraith is referring to wholesale prices. However, we will argue later that large retailers have only a very limited interest in passing on savings to customers. Finally, it should be remembered that for power to be countervailed there must be prevailing power evidenced by high prices demanded by high profit megaorganizations who jointly dominate a market.

\section{LARGE RETAILERS AND FRANCHISED DEALERS}

We do not disagree with Galbraith that countervailing power can occur in the American market, but we do question whether it is a major balancing mechanism, and question further the extent to which it operates in the interest of the customer. One weakness in Galbraith's argument is the assumption that retailers must necessarily act as the consumer's representative (Galbraith, 1952: 117), rather than form a new oligopoly. Whereas in the traditional free market the manufacturer attempted to minimize costs and maximize price within the competitive range, we see the large retailer's interest is to buy at the lowest price and sell at the highest possible competitive price. For Galbraith, the retailer
Monopoly Capital and Countervailing Power

maximizes profit by championing the consumers' interests and therefore receiving their economic support. It is our contention that the growth of large retailers such as Sears, Safeway, etc., are new forms of oligopolies and need pass on prices to the consumer only slightly lower than those otherwise controlled by the manufacturer. Therefore, it is in the interest of the large retailer to have manufacturers, who retail the merchandise through franchised stores and who control prices to those stores, to ultimately pass on these prices to the consumer. For example, let us assume that Goodyear sells its tires through its franchised dealership for $\$ 60$, and Sears in a large volume, multi-year contract buys the same tire (with the addition of a Sears' label) from Goodyear for $\$ 30$, and sells it for $\$ 55$ (see Figure $4 \mathrm{~A}$ ). If Goodyear raises its retail price to $\$ 65$ because of increased manufacturing costs, materials costs, and a desire for even higher profits, etc., it is in Sears' interest to raise its price to $\$ 60$ and therefore increase its profit (see Figure 4B).

Perhaps Sears can countervail the market power of Goodyear through multi-year contracts and has the threat or bargaining power not to renew them, or to seek a better deal from a competitive manufacturer. In fact Sears can and does purchase foreign made goods, thus to an extent circumventing U.S. oligopolies. For example, Sears first purchased its radial tires from a foreign manufacturer, but once U.S. tire companies began to produce radials, Sears signed its next contract with one of them. Galbraith's theory assumes that Sears would pass on any savings from the new contract to the customer, but as can be found by contemporary price comparisons little or no savings are passed on. In fact, it is a common practice of large retailers to make certain minor specification changes for their products such that a slightly poorer quality product at perhaps a lower price is passed on to the customer. The retailer can then compete against the manufacturer with a lower-priced, and slightly lower quality item. It seems hard to argue that this is in the consumer's best interest, or that this exemplifies the countervailence of market power.

According to Galbraith "[r] etailers are required by their situation to develop countervailing power on the consumer's behalf" (Galbraith, 1952:117). Supposedly it is the interest in 
volume sales which causes this 'required' countervailence. But as we have pointed out this is a wholly erroneous view. The confluence of interest between large retailers and consumers is a phenomenon of very limited range. Large retailers have an interest in large volume sales. In pursuit of that interest there are a number of means which include advertising on the one hand and selling shoddy goods on the other. Easy access to stores, comprehensive credit arrangements for consumers, and better service after the sale are other strategies pursued by large retailers. In short, offering lower prices to the consumer and thus countervailing the power of large manufacturers, is only one among many strategies available to large retailers to keep volume sales.

Furthermore, even when lower prices is the strategy pursued by large retailers, the confluence of interest between them and the consumer is very limited. The retailer has an economic interest in offering prices which were sufficiently lower than other retailers to attract business from them. Beyond that point the large retailer has no interest whatsoever in offering lower prices to the consumer. As pointed out above, this means that if manufacturers have the power to raise prices in other retail outlets, then the large retailer has an interest in readjusting his prices upward to a point again just sufficiently below that of other retailers to attract volume business. The image which Galbraith draws is one of large retailers stoutly defending the interests of customers. Clearly this image is wrong-headed.

If the extent of confluence of interest between large retailers and consumers is at most limited to a small and constantly readjusting price advantage, itself determined by prevailing prices, then the central issue to be considered is how producers control their markets. If it is found that producers have the means to set prices largely as they choose, if there are means by which they can insulate themselves from consumer power outside their relationships to large retailers, then, as we have seen from the foregoing discussion, that power will not be countervailed to any significant extent by large retailers. This same point can be stated in terms of market prices. If manufacturers can set prices at such a point that very large profits will result, then they have strong prevailing power, only a small increment of which will, at most, be countervailed by large retailers. Therefore, let us turn to the consideration of one of the mechanisms by means of which large producers do insulate themselves from countervailing power.

\section{FRANCHISED DEALERS, PREVAILING POWER,} AND INSULATION FROM COUNTERVAILING POWER

As even the most casual observation of contemporary economic practice will indicate, a typical marketing system of monopoly and oligopoly capital is to sell first to franchised dealers who in turn sell to consumers. As we analyze this two-stage exchange system it will be seen that one of its effects is to insulate large capital from the consumer in such a way that the prevailing power exerted by large capital over its franchised dealers is not countervailed. This structure is then the system which determines prevailing prices and in turn determines the price from which large retailers do, at times, deviate slightly. Since, as we will show, one consequence of this system is that prices to dealers and thus to consumers can be set within very broad limits at the price desired by large capital, no effective countervailence will occur.

In Figure 5 we have represented the network connecting a large capitalist corporation such as General Motors with a subset of five of its dealers and have represented the consumers who buy from those dealers by a large box below that set. Furthermore, we have superimposed upon this actual network a subset of potential dealers who could under certain conditions be brought into the network by the corporation to displace any of the existing dealers. As Leonard and Weber (1977:137ff).imply, large auto manufacturers act to encourage new dealers to enter the network of existing dealers displacing those already established. There are training schools for new dealers established by the corporation and financial aid to new dealers is made available by the corporation. As a consequence there is what could well be called a 'reserve army' of dealers ready and waiting to be included in the franchising system. Who are these people? Clearly they come from a variety of origins: salesmen of existing dealers, shop managers, local dealers with an interest in expansion to further dealerships and local members of the business class. But who they are matters 
Mid-American Review of Sociology

less than the fact that such a reserve army of potential dealers does exist.

As Marx pointed out in Capital (Marx, 1967:637ff) the effect of the reserve industrial army is to depress wages to the lowest possible level. In other words the existence of the reserve industrial army of proletarians allowed the capitalist to set the price of labor at the point desired by the capitalist and independent of the wills of any individual proletarian. Similarly, the effect of the reserve army of dealers is that corporations can set prices to dealers at the desired point and independent of the wills of individual dealers. Of course, in this instance the consequence is to set prices as high as desired. Furthermore, as we shall see, the effect of this structure is, beyond price fixing, to place a number of further burdens on the franchised dealer. However, before proceeding to those effects let us consider the dynamics of the network and its effects.

Let us consider the instance of a given dealer who wants to gain a better price from the corporation for the cars (or for any other commodity) which he buys. Since there are potential dealers in the system, the corporation can, at little or no cost, simply refuse the bargain with that dealer (as a capitalist could refuse to bargain with any worker in the presence of a reserve industrial army) and instead could threaten to displace the dealer in favor of one from the potential network. Similarly, consider a dealer who wanted to resist the imposition of high prices. Again such resistance would have no base in the structure due to the ease of his displacement. Thus, the dealer is not in a position to countervail the power of the corporation, and instead can be expected to accept the demanded price and attempt to pass it on to the consumer, quite regardless of what that price is.

Now let us turn to the effect of contracts in the relations between the corporation and its dealers. Let it be assumed that the contract has $\mathrm{N}$ clauses each of which can be written either in the interest of the corporation or in the interest of the dealer. Given the structure of the system a result similar to the one found in the case of prices would be expected, such that all $\mathrm{N}$ clauses would be written in the interest of the corporation.

One clause which is an element of any contract is the duration over which it is binding. Such a clause can also specify the
Monopoly Capital and Countervailing Power

conditions under which either party to the contract can withdraw. Again if these elements are drawn in the interest of the corporation, the effect of the structure as it existed at a given point $T$ is extended over the time period of the contract. Thus, for any one contractual relationship between a corporation and its dealer, only at the point at which the contract is negotiated and signed need there be a reserve army of dealers. Once the contract is signed under that structural condition, the power exercise can be sustained for the period of the contract regardless of whether the structure is or is not maintained! Thus, the first effect of the contract is to sustain the prevailing power over dealers beyond the structure over the time period of the contract.

Given the first effect, a second effect follows. Consider the larger network of $\mathrm{N}$ dealers. For any given time period, let it be assumed that all but one are under (long term) contract. That one dealer is now entering into negotiations for a new contract. Thus, only that one dealer faces the whole of the reserve army of dealers which can brought to bear. Thus, his structural position is very disadvantageous. Consequently, since dealers need be contracted only at intervals, the corporation can maintain its power position through only a very small set of potential dealers.

In light of the foregoing let us turn to the situation of the consumer. Since 'wholesale' prices have been fixed to all dealers with whom he can do business, it follows that the best price that the consumer can obtain is one only slightly higher than that wholesale price. Thus, the power which was exerted over the dealers by means of the reserve army of dealers is passed directly on to the consumer. Thus, power over dealers resolves itself into power over consumers, a prevailing power which is not countervailed.

The fact that mega-organizations can establish prevailing power over their dealer networks and consequently over the consumer is of the greatest possible importance as will be seen as we move to the consideration of the relationship between dealers and consumers for, contrary to what might be expected, it is again the dealer who is in a disadvantaged position. In order to understand that position it will be assumed in the following that the consumer has a set of dealers from whom he can buy and knows 


\section{Mid-American Review of Sociology}

the wholesale price of the commodity. (In the case of autos, for example, this latter information is easily available.)

The consumer needs to buy only one car, but there are a larger number of dealers to whom he can go. Were any one of these dealers to refuse to give in and sell at the price only slightly higher than the wholesale price, the consumer could go elsewhere. As a consequence the set of consumers are in a position, if they act rationally, to play off the set of dealers against one another. By iterating between dealers the price paid can be expected to be little more than the wholesale price. In fact, anyone who has bought a car this way knows how the system works and knows its effects. Thus, again, the dealer finds himself in a disadvantaged position.

However, the advantaged position of the consumer is over the dealer alone, and does not extend beyond him to the corporation. Thus, even the most rational buyer cannot affect the wholesale prices which had already been set by the megaorganization, and since he cannot, prevailing power has been exercised over him.

\section{SOME PROPOSITIONS AND SUPPORTIVE EVIDENCE}

The foregoing interpretation followed from a formulation for a two-stage exchange relationship. The question which now arises is what kind of empirical evidence would support this formulation? At least the following empirical propositions fall out of the foregoing analysis as it is applied to automotive two-stage exchange networks:

(1) The profits enjoyed by at least the largest manufacturers would be expected to be far above the level expected were their power to have been countervailed.

(2) Contracts between manufacturers and dealers would be highly advantageous to the former.

(3) Franchised dealers' profits per auto sold could be expected in at least some cases to be very low, and on the whole not to be high (the expected level being dependent upon the rationality of buyers).
Monopoly Capital and Countervailing Power

One further proposition could be added if it is the case that dealers are squeezed between the corporation and the consumer. Then, it could be inferred that other sources of profit would be sought by dealers. In fact there is support for all of the foregoing empirical propositions.

Discussion of Proposition 1: Leonard and Weber (1977: 141) indicate that during the period from 1960 to 1967 General Motors earned 20.5 percent annual profit on investments, Ford Motor Company earned 14.3 percent, and Chrysler Corporation earned 11.8 percent. These data, when compared to Proposition 3 's data below, clearly indicate the lack of any countervailing influence of the dealers. According to Vanderwicken (see Farberman, 1977:452) who studied medium-sized dealerships in Cleveland, Ohio, auto dealers have earned less than one percent on sales.

Discussion of Proposition 2: Auto franchised dealers operate under very restrictive agreements with the auto manufacturers (Leonard and Weber, 1977:137). Of course, in part this is due to their dependency upon the manufacturers for the initial capital loans to establish the agency. In these contracts the manufacturer sets the terms of the selling agreement, which requires the dealer to sell and service that line of cars, stock parts, meet minimum sales quotas established by the manufacturer, and allow the manufacturer to cancel franchises for violations of certain conditions. White refers to this relationship as a 'forcing model,' where the manufacturer places the dealer under tremendous pressure to sell the autos as fast as possible, since the dealer's capital is tied up in unsold cars; and/or loan interest rates which accrue for the cars sitting on the lot (Farberman, 1977:450).

Discussion of Proposition 3: As previously mentioned, car dealers earn a minuscule margin of profit on the sale of new goods-far below that of independent retail businesses. Vanderwicken (Farberman, 1977:452) provides an example from a medium-sized agency in Cleveland, where a new car was sold for $\$ 3,337$, of which $\$ 3,025$ was paid to the manufacturer, $\$ 90$ for the salesperson's commission, $\$ 43$ for wages and salaries, $\$ 30$ for advertising, $\$ 28$ for loans and interest, $\$ 27$ for miscellaneous, $\$ 24$ for taxes, $\$ 22$ for rent and maintenance, $\$ 16$ for dealer 
preparation and pre-delivery work, $\$ 9$ for free customer service, $\$ 7$ for employee benefits, leaving a new profit of $\$ 16$ for the new car. The additional dealer's obligation of providing maintenance service can be viewed as a 'necessary evil' to maintain the franchise, since the franchise contract strictly limits service charges and profits. It is not surprising that some dealers' reaction to this obligation is to attempt to turn it into a more profitable operation by illegal means. As reported in a Senate Judiciary Subcommittee hearing in December 1968, a series of criminal activities related to auto dealership service practices have been identified, such as charging for labor time not actually expended, billing for unnecessary repairs, or repairs not performed, and using rebuilt parts and charging for new ones. Similar illegal schemes have been discovered oriented towards duping the manufacturer with reference to new car warranties for parts and services. Farberman (1977:454) argues that the criminal behavior of the auto retailers is a direct consequence of the system imposed by the limited number of oligopolist auto manufacturers.

\section{CONCLUSION}

Though it has been over two decades since Galbraith wrote American Capitalism, it can be argued that he should have then recognized the predominance of large capital. Before 1920 Max Weber (1953:325) pointed out that Standard Oil had total domination over gas dealerships, a time at which Galbraith considered countervailing power to be developing. Weber stated that owners (manufacturers) could maintain even partial monopolies if they could 'prescribe' prices to both exchange partners and competitors, i.e.," . . . if by [their] own conduct, they could impose upon [exchange partners and competitors] a way of conduct according to [their] own interests, without... imposing on them the slightest 'obligation' to submit to this domination" (Weber, 1953: 325).

Galbraith failed to describe the structures and processes through which corporations protect themselves from countervailence. Consequently, he presents a one-sided view and has obscured how countervailence is neutralized in our society.

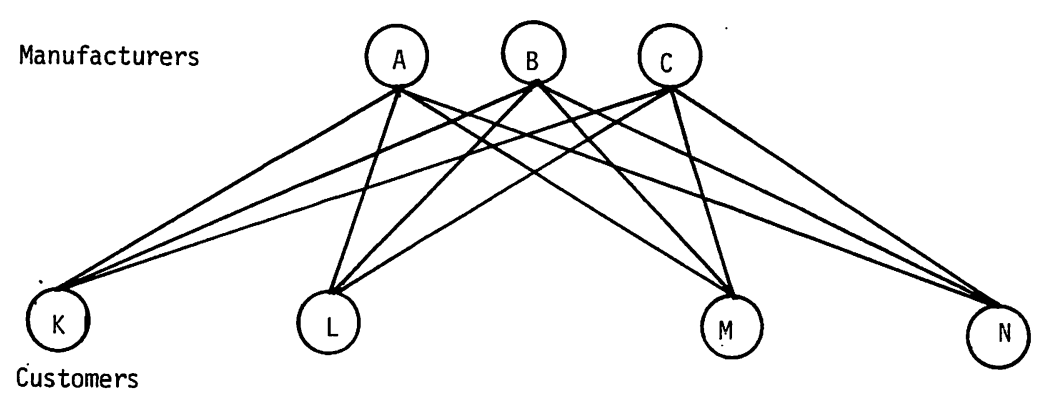

Figure 1: Potential Network of the Open Market System

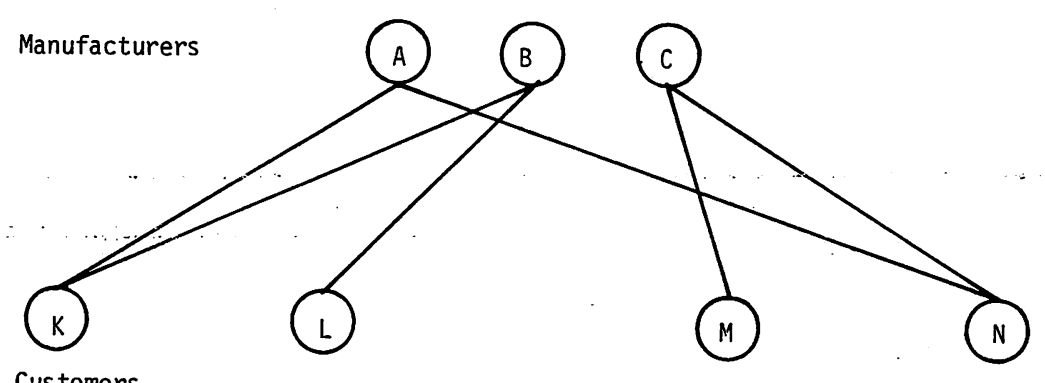

Cus tomers

Figure 2: An Actual Network of the Open Market 


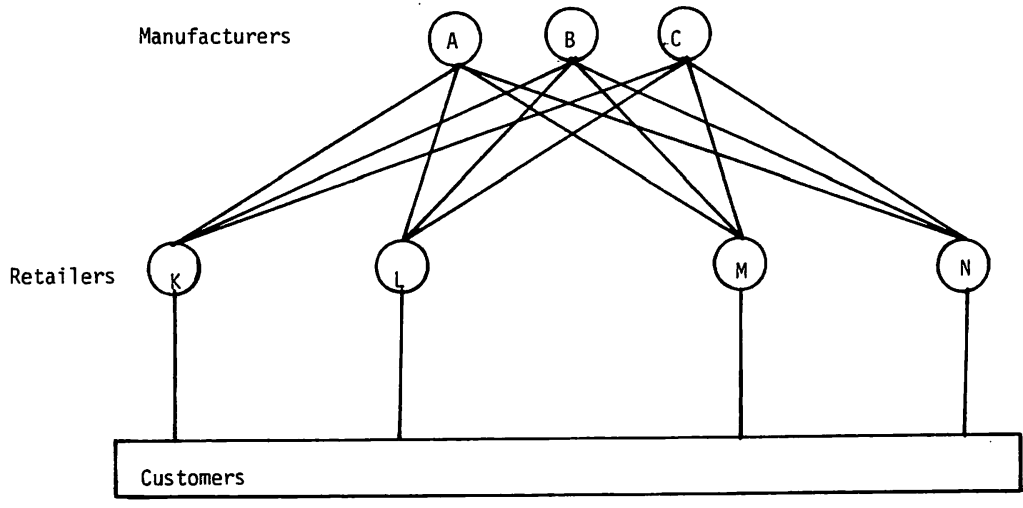

Figure 3: Potential Network of Manufacturers, Retailers, and Customers

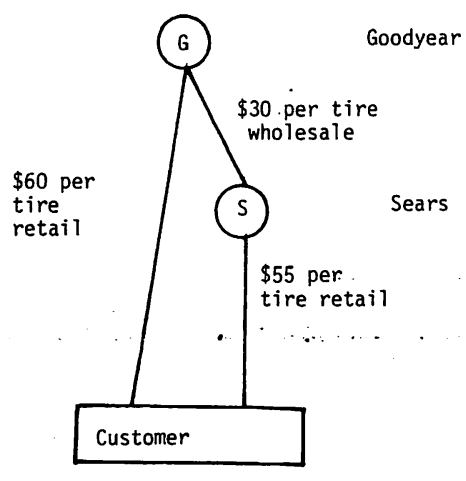

4A: Time I



4B: Time II
Figure 4: Examples of Goodyear and Sears Contractual Relationship and Retail Tire Pricing

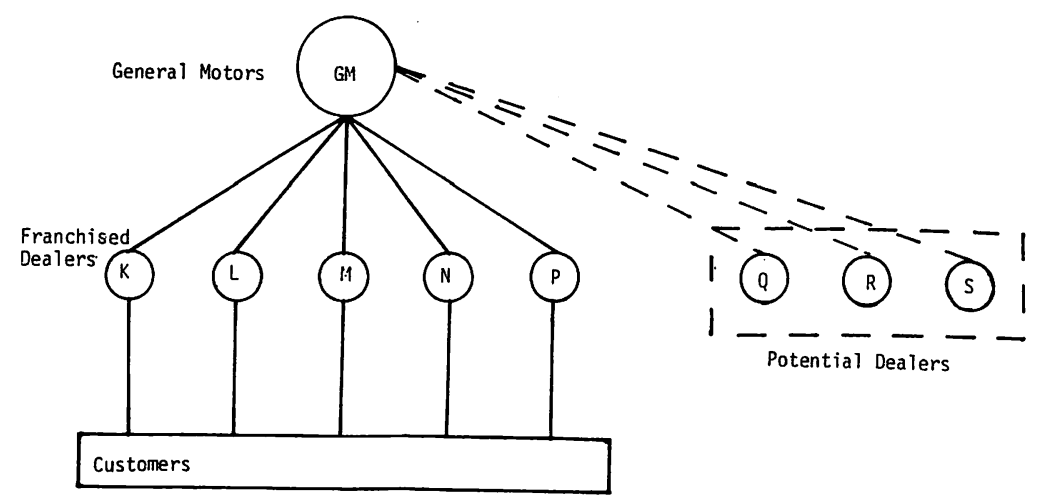

Figure 5: Potential and Actual Retailing Markets for an Auto Manufacturer

\section{REFERENCES}

Farberman, Harvey A.

1977 "A criminogenic market structure: the automobile industry." Pp. 431-456 in J. Galliher and J. McCartney (eds.), Criminology: Power, Crime, and Criminal Law. Homewood, Ill: Galbraith, Kenneth

1952 American Capitalism. Boston: Houghton Mifflin Company. Leonard, W.N. and N.G. Weber

1977 "Automakers and dealers: a study of criminogenic market forces." Pp. 133-150 in G. Geis and R. Meier (eds.), White Collar Crime. New York: The Free Press.

Marx, Karl

1967 Capital, Vol. 1. F. Engels (ed.), New York: International Publishers.

Weber, Max

1954 On Law in Economy and Society. M. Rheinstein (ed.), Cambridge, Mass.: Harvard University Press. 